International Interactions, 39:119-143, 2013

Copyright (C) Taylor \& Francis Group, LLC

ISSN: 0305-0629 print/1547-7444 online

DOI: $10.1080 / 03050629.2013 .768458$

\title{
Going the Distance: The Price of Projecting Power
}

\author{
JONATHAN N. MARKOWITZ and CHRISTOPHER J. FARISS \\ University of California, San Diego
}

The central purpose of this article is to establish the relationship between power projection, technology, and economic power. How economically powerful does a state need to be before it can afford the capital intensive technologies, foreign bases, and military and logistical forces associated with global power projection? The specific research question we focus on in this article is: What determines how far states send their military forces? We argue that as the costs associated with projecting power decrease or as the wealth necessary to project power increases, states will project power more frequently and at greater distances. We use a system level time series analysis from 1870-1936 and a dispute level analysis on all militarized international disputes from 1870-2000 to test these propositions. This article is the first to demonstrate empirically that the distance and frequency of power projection is a function of the cost of projecting power. We close with a discussion of contemporary states building power projection capabilities and how future research might build from our research to explain this behavior.

Earlier versions of this paper were presented at the 2011 meeting of the International Studies Association and as a poster at the 2011 IGCC So-Cal Symposium at the University of California, Irvine, and the 2010 meeting of the Peace Science Society (International). We would like to thank Megan Becker, Alex Braithwaite, Scott Bennett, Erik Gartzke, Miles Kahler, David Lake, Yon Lupu, Paul MacDonald, Blake McMahon, Alan Rozzi, Christina Schneider, and Branislav Slantchev for comments on earlier drafts of this paper. All data and code used in this project are publicly available at a Dataverse archive maintained by the authors, http://hdl.handle. net/1902.1/18567, and are cross posted at the Dataverse archive maintained by International Interactions: http://dvn.iq.harvard.edu/dvn/dv/internationalinteractions. All questions regarding the data and code should be directed to the authors. Both authors contributed to study design, data collection, analysis, and preparation of the manuscript.

Address correspondence to Jonathan N. Markowitz, University of California, San Diego, Social Sciences Building, 9500 Gilman Drive, La Jolla, CA 92093-0521, USA. E-mail: jnmark@ ucsd.edu 
KEYWORDS distance, geography, loss of strength, militarized interstate disputes, power projection

In the early twentieth century, a number of economically ascendant powers, including Germany, Japan, and the United States, plunged their newfound wealth into the construction and deployment of fleets of battleships, expeditionary forces, and distant bases. However, during the second half of the twentieth century most great powers abandoned the high seas and mothballed their battle fleets. At the dawn of the twenty-first century, we are witnessing a reversal of this trend: China, India, Brazil, and Russia, and a group of rising minor powers (such as South Korea, Norway, and Australia) have been modernizing by building submarines, warships, aircraft, and expeditionary forces. Why are these states building power projection capabilities again and how much of their behavior can be explained by their economic ascendance or technological innovation?

Conventional wisdom among realists and military historians is that the relationship between economic power and the development and deployment of military power is a tight one (Kennedy 1989; Mearsheimer 2001). These scholars contend that as states become economically powerful, they generally choose to build and project military power. But is this really true, and if so, how strong is the relationship between economic power and military power projection empirically? A second set of scholars argue that not just economic power, but technology and its effect on the cost of projecting power determines the distance and frequency with which states deploy military force (Bean 1973; Boulding 1962; Dudley 1991; Quester 1977). Our paper provides one of the first empirical analyses of how the cost of projecting power affects the distance over which states project power. The specific research question we focus on in this paper is what determines how far states send their military forces?

This question is important because it is impossible for actors to engage in interstate war, expansionist foreign policies, or the production and deployment of coercion without engaging in power projection. The ability to project power is therefore a necessary, but not sufficient condition for war, empire, and the establishment and governance of regional and global orders. In short, states cannot engage in war with other states without projecting power, and they cannot maintain global orders without the ability to project power.

We postulate that there are two principle mechanisms that reduce the cost of projecting power: (1) technological innovation reduces the cost of shipping force over distance; and (2) the relative economic scale and wealth of a state determines the degree to which they can leverage scale economies to reduce the cost of deploying force over distance. We test each of these propositions separately. 
States face a variety of constraints in terms of their ability to project military force. The process of transporting, resupplying and maintaining soldiers far from home is enormously expensive. However, the distance at which states have projected military power has varied over time. Technological innovation has played a large role in terms of reducing the cost of transporting military forces over distance (Dudley 1991; Smil 2007). Innovations such as the steam engine and railroad greatly reduced the costs of transporting goods over land and sea. These technological innovations lowered the price of transporting military equipment, supplies and personnel, and thus decreased the cost of projecting power. We expect that when there is a decrease in the cost of projecting power, states will project military force greater distances from their capital. An observable implication of our theory is that the maximum distance at which states are involved in militarized interstate disputes (MIDs) will increase as the costs of projecting power decreases.

In the remainder of this paper we review the literature on power projection. We then outline a theory of power projection and distance. We then test hypotheses derived from the theory. The results suggest that states are sensitive to the cost of projecting power in terms of both distance and frequency. These findings have implications for both the shifting distribution of global power and the potential for new military technologies to alter the frequency and distance with which states project power. We end with discussion of the implications of our findings.

\section{PREVIOUS RESEARCH}

The literature on interstate conflict has long recognized that conflicts cluster in geographic space (Aleprete and Hoffman 2012; Braithwaite 2006; Enterline 1998; Gleditsch 1995; Lemke 1995; Most and Starr 1980, 1989; O'Laughlin 1987; Siverson and Starr 1990; Starr 2002; Starr and Most 1976; Starr and Thomas 2005; Vasquez 1995). However, our theoretical focus and empirical analysis focuses on the ability of states to project power past shared borders and regional neighborhoods. The relative ability of states to project power determines which states can fight, acquire a sphere of influence and consequently compete over the leadership of a global or regional order. In short, the relative ability of states to project power has consequences for both who gets to rule, the level of hierarchy they choose to impose (Lake 1999, 2009) and how they decide to distribute scare resources such as land, labor, and capital.

The ability of states to project power determines in part both the size of states (Bean 1973; Dudley 1991; Lake and O'Mahony 2006), and the relative ability of states to govern and extract from those under their rule (Olson 1993; Olson 2000; Scott 2009). Just as the ability of government to project power within the states has affected the size of states and the consolidation 
of their rule, relative power projection capabilities also affects the size of a state's sphere of influence.

A state's ability to influence the terms of a bargain at or within its borders is largely a function of the total coercive power of the state. Powerful states can maintain their monopoly on the use of force, enforce their laws, control the exchange of commerce, tax their citizens, and defend their rule from internal and external challenges. However, the ability of a state to influence bargains over issues and individuals that are geographically distant from the origin of the state's power are constrained by the ability of such a state to project power. In sum, the hierarchal orders that states build are largely constructed upon a foundation of hard military power, the use of which is mediated by distance (Lake 1999, 2009).

Boulding (1962) argues that distance weakens power and models this tendency through the loss of strength gradient. As Buhaug and Gleditsch (2006:188) write, "Projecting force to distant parts of the world is much more costly than attacking one's neighbor." Distance, in effect, places a limit on power because it weakens the effect of power (Gartzke 2009; Mearsheimer 2001). All things equal, the further away a state wishes to project power, the weaker that state's power will become relative to its target. Because of the limiting role of distance on a state's power, states are most likely to fight wars with geographically proximate or contiguous states (Boulding 1962). However, more powerful states are able to traverse longer distances (Bueno de Mesquita 1981; Buhaug and Gleditsch 2006; Senese 2005). As the cost of projecting power decreases, states will be able to project power at greater distances thereby entering into a greater number of contests over governance with other states.

Posen (2003) discusses the role of contested zones in generating military competition and the potential for conflict. A contested zone is a geographic space in which political control is unclear because states' military reach overlap. It is "unclear" because more than one state possess the military capability to compete over the space and it is "unclear" which states possess sufficient capabilities or resolve to prevail in the advent of conflict. A zone is not contested if one state's relative power and resolve are so dominant that there is no uncertainty about who would prevail in a conflict. A decrease in the cost of projecting power increases the distance over which states can project power and reach one another, therefore increasing the number of potential contested zones. The greater the number of potential contested zones, the greater the opportunity for military competition. A reduction in the cost of projecting power means that states with opposing interests that previously could not reach one another, and therefore could not militarily compete, now can. For example, prior to the 1850s the United States and Japan could not reach one another militarily and therefore there were no contested zones between the two states. However, as both states became more powerful, and as the cost of projecting power decreased, each state 
could reach one another, and their opposing interests generated contested zones in the Asia Pacific. This in turn generated incentives to build stronger power projection capabilities to compete over the governance of these spaces.

\section{DEFINITION OF POWER PROJECTION}

We define power projection as the deployment of military force beyond one's own capital. In this sense nearly all states possess some ability to project power; however for most states that capability is extremely limited. We are principally interested in states that can project large amounts of military power globally. The more power a state has and the less that power decays over distance, the higher its power projection capability. Thus, there are two variables that interact to determine a state's ability to project power: the amount of power a state has, and the degree to which that power decays over distance. For the purposes of this paper we focus on the distance and frequency that states project power rather than the amount of power they can project over that distance.

It is only very recently that technological innovation has lowered the cost of power projection enough to allow states to fight, interact, and extend political order on a global level. Without the ability to transport forces over great distances, great powers would be confined to their own regions, and there would be no global system as we think of it today. As the cost of power projection has decreased, the world has become smaller, and a set of distant and separate international systems have been merged into a single global system.

This is not to say that distance is dead or does not matter (Buhaug and Gleditsch 2006). Russett and Oneal (2001:87) empirically demonstrate that in terms of who states fight "distance is the most important constraint." Even with modern technology, Mearsheimer (2001) argues that the cost of projecting power is so great the world's oceans insure that there can be no global hegemon. The literature acknowledges that distance constrains power, but what determines how much state power is restrained by distance?

A large part of what distinguishes a regional power from a superpower is the difference in power projection capability. ${ }^{1}$ Strong power projection ability matters because it allows states to employ military force over long distances, and thus increases the number of states that a country can coerce, deter, attack or defend (Blechman and Kaplan 1978). States with a robust power projection capability can export security and this allows them to engage in a greater number of cooperative security relationships. ${ }^{2}$ The ability to

\footnotetext{
${ }^{1}$ See Mearsheimer (2001:135) for a discussion.

${ }^{2}$ See Lake (1999:280) for a discussion.
} 
project power allows states to reassure allies and deter potential adversaries. ${ }^{3}$ For example, states can deploy military forces to more distant regions to demonstrate resolve, and this allows them to enhance the credibility of their deterrent or coercive threats (Huth and Russett 1984; Russett and Oneal 2001). The further a state can project military power, and the more precise, discriminate, and destructive that force is, the more influence a state will have over international actors, and thus on the international system itself (Mahan 1890, Modelski 1987, Modelski and Thompson 1988, Posen 2003). In sum, power projection is a tool states use to exercise influence over the distribution of resources in the international system.

\section{HOW TECHNOLOGICAL INNOVATION LOWERS THE COST OF PROJECTING POWER}

When projecting power, states seek to increase their capabilities and lower their costs (Pugh 1986). At its core, this is a logistics problem that states have attempted to solve through technological innovation. Bean (1973) argues that shifts in technology alter technological economies of scale, which determine whether states contract or expand. Dudley (1991), (borrowing heavily from Bean (1973)) contends that state size and capacity to extract taxes are a function of the price of controlling territory. For states, the price of controlling territory is determined by the degree to which technology and innovation favor military scale economies.

Certain technologies and innovations instead reduce scale economies and make it more expensive for states to control territory. States that can utilize technological scale economies with regard to transportation, weapons, logistics, and communications should be able to project power greater distances. Technology is relevant to our theory because it helps determine the cost of projecting power. When technology lowers the cost of projecting power, we should observe states projecting military force with higher frequency and at greater distances. This is important because it not only affects how far a state can project power, but whether it can project power cheaply enough such that the benefits outweigh the costs.

\section{THE RELATIONSHIP BETWEEN POWER PROJECTION AND WAR}

Increased interaction between states, a rise in the number of security commitments $^{4}$ of powerful states, and greater uncertainty about relative

\footnotetext{
${ }^{3}$ See Blechman and Kaplan (1978:8) for a discussion.

${ }^{4}$ Assuming that the returns for security cooperation are constant, a decrease in the cost of power projection should result in an increase in the number of cooperative security arrangements. See Lake (1999:281) for further discussion.
} 
resolve and capability will all make war more likely to occur at greater distances. As states project farther from their home, the number of state interactions will increase. ${ }^{5}$ An increase in the number of interactions between states means that opportunities for conflict will be greater (Most and Starr 1980; Most and Starr 1989; Siverson and Starr 1990; Starr and Most 1976). In other words, states are more likely to fight states that they interact with more frequently (Gartzke 2009; Gartzke and Rohner 2011; Hegre 2008). Therefore, as the ability of states to project power over distance increases, their interaction with distant states should also increase, thus heightening the probability of conflict with these states.

The greater distance that states fight from home, the smaller fraction of their total capability they can bring to bear. This leads to greater uncertainty about the capability and resolve (Gartzke 2009). Greater uncertainty about the projecting state's resolve and capabilities would explain why states are more likely to fight far from home, and why they are more likely to defeat local forces (Bueno de Mesquita 1981; Gartzke 2009). States that are proximate have greater information about whether a state will fight and if they will prevail. In contrast, distant states are more likely to underestimate the capabilities or resolve of the projecting state and fight a war for which they are overmatched.

\section{A THEORY OF POWER PROJECTION}

Like many authors before us (Lake 1992; Olson 1993; Olson 2000; Tilly 1992; Tullokc 1980), we define rents as the extraction of wealth through limiting economic competition by governments. We assume that states are unitary, rent-seeking actors, and that rents are geographically distributed. State efforts to secure external rents, those not obtainable within the territorial boundaries of the state, are a function of the costs and benefits of extracting internal versus external rents. ${ }^{6}$ In seeking such payoffs, states are sensitive to the cost of procuring them, which is partially a function of the costs of investment at home compared with the costs of seeking them abroad. A state can therefore choose to obtain such rents by force, coercion or the voluntary exchange of security for political influence globally (Lake 1992) just as it can do so domestically (Olson 1993; Olson 2000). The state, in our theoretical framework, is therefore analogous to the firm in its expansionistic behavior.

Both states and firms seek profits. However, states primarily do so through seeking rents. ${ }^{7}$ At each step of expansion, both firms and states

\footnotetext{
${ }^{5}$ See Farewell (1972:XVII) for further discussion.

${ }^{6}$ We define internal rents as garnered from inside the state; external rents are rents extracted from outside the border of the state.

${ }^{7}$ This is not to say firms do not seek rents, but that rent-seeking is a primary method of generating profits for states.
} 
make a calculation as to whether local investment or foreign investment will net a higher return. States, like firms, invest globally (externally), when the expected gains per unit expended for external rents exceed the expected per unit benefit gained from internal rents. States project power at greater distances when the cost of obtaining additional rents internally is greater than the costs of extracting rents externally. States may obtain rents using coercion but this is not necessary for power projection to occur. States, such as the United States, project power for a variety of security related reasons such as the protection of sea lanes (Posen 2003), and the defense of allies (Blechman and Kaplan 1978; Meernik 1994; Meernik 2008). Such power projection behavior does not directly lead to the use of force or breakdowns in bargaining with other states. However, power projection does lead to more interactions that in turn can end in such breakdowns.

Following Lake (2009), we suggest that states have a variety of means with which to secure goods abroad. The use of force is just one policy tool that can be used for this purpose. Critically, however, states project more power at greater distances as the cost of projecting power decreases through either technological innovation, or an increase in the relative ability of states to afford power projection capacity. Therefore, wealthier states, or states with greater levels of technological sophistication project power at greater distances.

As the cost of projecting power decreases, states project power at greater distances and the number of state-by-state interactions necessarily increases. It is therefore a consequence of this increase in the number of interactions that, given random breakdowns in bargaining because of information asymmetries, more interactions will lead to more bargaining failure and therefore more conflict (Fearon 1995; Gartzke 1999). In other words, states project power in order to increase their bargaining leverage with other states but sometimes conflicts still occur. Conversely, states that do not have the opportunity to interact also do not have the opportunity to behave coercively toward one another (Most and Starr 1989; Siverson and Starr 1990). An implication of the theory is that as the cost of projecting power declines, states will project power at greater distances from their capitals. If this relationship between the cost of power projection, and the distance at which states project power is true, we should be able to observe states engaging in MIDs at greater distances from their capitals because of the increasing number of coercive interactions and the possibility of bargaining failure. This logic leads to the derivation of several hypotheses:

H1: As the cost of projecting power decreases, the system will experience an increase in the number of militarized interstate state disputes, ceteris paribus.

$\mathrm{H} 2:$ As the cost of projecting power decreases, the system will experience an increase in the number of militarized interstate state disputes at greater distances from their capital, ceteris paribus. 
$\mathrm{H} 3:$ States with greater relative economic resources will participate in MIDs at greater distances from their capital than states with less economic resources, ceteris paribus.

\section{RESEARCH DESIGN}

Our research design allows us to examine the effect of a decrease in cost of projecting power on the likelihood of states engaging in Militarized Interstate Disputes at greater distances from their capitals over time. We test H1 and $\mathrm{H} 2$ by conducting a time-series analysis of the international system from 1870-1936. We examine this time period because the paucity of airpower prevents distortion of the measure of transportation costs, and because of the availability of data for the independent variables. The unit of analysis is the system-year from 1870-1936. The dependent variable is the number of MIDs that occurred within the system-year at a distance greater than some specified value of distance. We restrict the analysis to MIDs with a hostility level greater than or equal to 4 , which means that at least one of the states in the conflict dyad used military force, thus ensuring that we are only measuring instances in which military forces are deployed. ${ }^{8}$

We operationalize the distance variable as the geocoded distance from the projecting state capital $i$ to the location of the MID $j$. The projecting state is coded as the state that is fighting at the greatest distance from their capital. We construct this measure using the longitude and latitude coordinates from the MIDLOC v1.0 dataset (Braithwaite 2010, 2013) and the longitude and latitude coordinates for each state's capital city from the Distance Between Capitals dataset (Gleditsch 2013; Gleditsch and Ward 2001). The MIDLOC dataset includes latitude and longitude coordinates for the location of each MID from 1816-2001. We measure the distance between the location of the MID and the location of each participant state's capital location using data on the latitude and longitude coordinates of the states' capitals; thus, for each dyad, two distance measures are created. We calculate the distance using the following equation:

$$
D_{i j}=\operatorname{acos}\left(\sin \left(\operatorname{lat}_{i}\right)^{*} \sin \left(\operatorname{lat}_{j}\right)+\cos \left(\operatorname{lat}_{i}\right)^{*} \cos \left(\operatorname{lat}_{j}\right)^{*} \cos \left(\operatorname{lon}_{i}-\operatorname{lon}_{j}\right)\right)^{*} r
$$

Where $D_{i j}$ is the distance between state $i$ 's capital and $j$ the location of the MID. $\operatorname{lat}_{i}, \operatorname{lat}_{j}, \operatorname{lon}_{i}, \operatorname{lon}_{j}$, are the latitude and longitude locations for state $i$ and militarized interstate dispute $j$. The variable $r$ is the radius of the earth in kilometers, which is approximately $6378.7 \mathrm{~km}$.

\footnotetext{
${ }^{8}$ We selected this subset of cases to gain a more accurate measure of whether a state had actually projected military power. At lower levels of hostility, such as 3 or below, states can simply make a show of force, or threaten to use force and therefore might not actually be projecting power.
} 
By definition MIDs occur between two states. We therefore measure the distance between the capitals of both states and the MID, and take the longer of the two distances. It is this number that is recorded for the distance of the MID. Conflicts are assigned to a distance cohort based on the state that traveled the greatest distance from its capital to engage in the MID.? MIDs are placed in distance cohorts with cutoffs above $1000 \mathrm{~km}, 2000 \mathrm{~km}$, $3000 \mathrm{~km}, 4000 \mathrm{~km}$ and $5000 \mathrm{~km}$. For example, all MIDs occurring at less than $1000 \mathrm{~km}$ are removed from the greater than $1,000 \mathrm{~km}$ distance cohort. Note also that the distribution of MIDs within the international system varies over time; however, the general trend appears to be positive, while the cost of shipping is in decline (see Figure 1). Disaggregating the data into distance cohorts allows for a comparison of the effect of transportation costs on the number of MIDs occurring in each of the distance cohorts.

To test $\mathrm{H} 3$ we estimate a continuous dependent variable that measures the natural log of the distance between the projecting state's capital and the location of the MID to which the state projects power. Our sample for this test are all MIDs from 1870 to 2000. We use the same equation defined above to calculate this distance.

\section{Independent Variables}

For $\mathrm{H} 1$ and $\mathrm{H} 2$, cost of power projection is the main explanatory variable. We construct the measures of the cost of power projection as a proxy variable that measures global shipping rates over time. Data on the costs of shipping are drawn from Lake (1999). We use two measures in the tests below, both of which represent the cost to shipping goods within the international economy over the period of our study. First, the cost of shipping is defined by tramp shipping rates, and is constructed using an index from 1870-1936. This measure represents the cost of shipping goods across the Atlantic. We use this measure because a large portion of the cost of power projection is shipping military equipment, supplies and personnel over water. The cost of shipping is generally decreasing with the exception of the period during World War I. Second, we use the cost of shipping by Rail in Great Britain, which again is taken from Lake (1999). Rail Costs is a price series based on receipts per passenger mile traveled on all railways in Great Britain, in constant pounds.

\footnotetext{
${ }^{9}$ Note that our objective is to measure whether a state projects power past a given distance threshold, not whether states initiate a MID at a certain distance. Consider for example, the United States, which might project power 8,000 miles to the Taiwan Straights, but if the Chinese initiate the MID, then they would be coded as the aggressor. We are more interested in capturing the fact that the United States projected military power 8,000 miles rather than the fact that once the United States carriers were there, a MID was initiated by China. Who initiates the MID is often the result of chance or error (Gartzke 1999), whereas the decision to project force is a more deliberate choice. For this reason, and because we are trying to capture the decision to deploy military force over distance, we code the state that projected the greatest distance as the projecting state.
} 


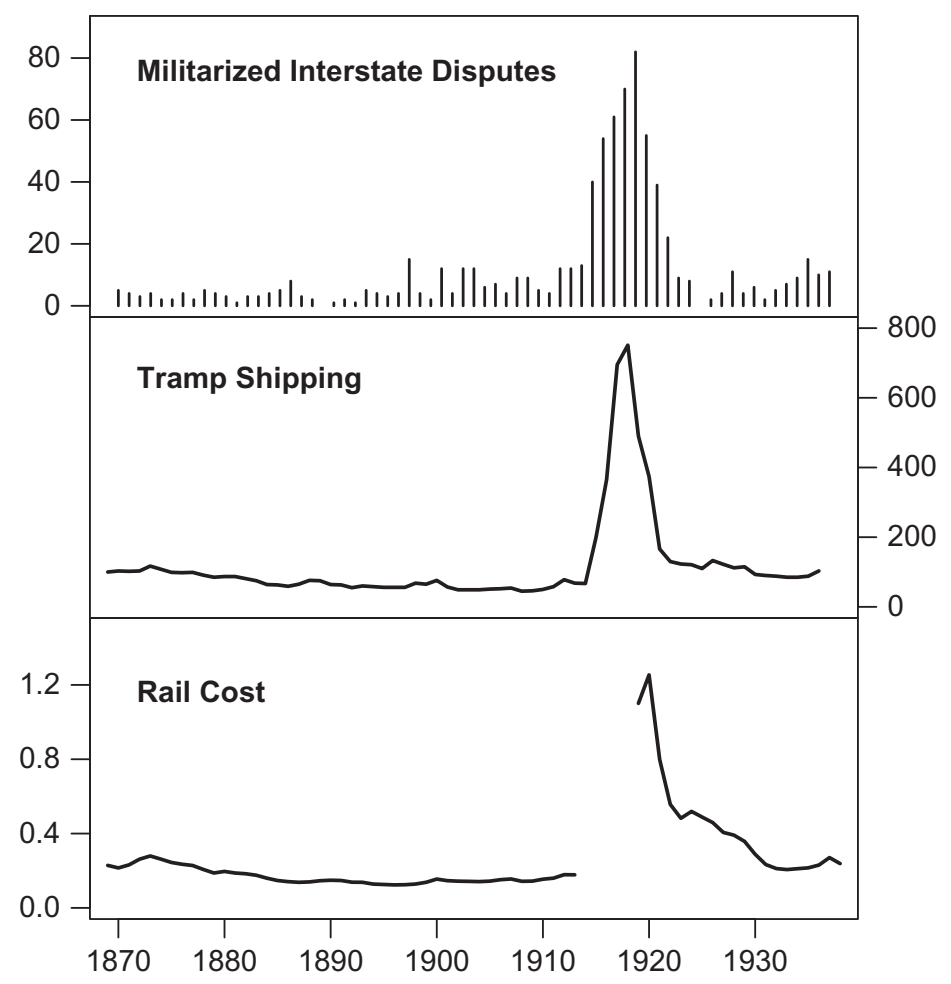

FIGURE 1 The count of militarized interstate disputes in the system each year from 1870-1936 (Maoz 2012). Tramp shipping is an index of shipping rates, $1869=\$ 100$ (Lake 2009). Rail costs is a price series based on receipts per passenger mile traveled on all railways in Great Britain, in constant pounds (Lake 2009).

Rail costs are a proxy for the more general trend in transportation costs over the study period. These variables represent the best proxy for global shipping rates during this time period because they each capture yearly changes in this cost and are taken from Great Britain, which was highly integrated in the global economy during this period. For this reason as well, these measures are conservative given that shipping costs are likely lower for Great Britain, a state with a large, technology advanced fleet, than the average global shipping cost. It is reasonable to suggest that governments may be able to pay a somewhat lower price than the market rates for shipping, however it is unlikely that the price that governments pay to ship goods will have no relationship to the market cost. Therefore, these measures are likely less than the true shipping rate and also are likely to fluctuate less than the "true" global rate of shipping during this period. This downward bias should reduce the effect of these shipping variables on the frequency of global MIDs. ${ }^{10}$

\footnotetext{
${ }^{10}$ In future research, we develop a measurement model that estimates the "true" value of global shipping using computational measurement tools developed for comparative and international relations research
} 
In order to control for the effect of industrialization, we borrow a measure from Lake (1999) that takes into account the level of industrialization. Industrialization is measured using energy usage per capita in the United Kingdom. Lake (1999) draws energy usage and population data from National Capabilities Dataset (Singer 1987).

Note that each of these variables enter the statistical models described below lagged one year in order to avoid issues of temporal causation. Also, a one-year lag of the dependent count variable enters each of the count models to control for the possibility that militarized interstate disputes that occur in year $t$ - 1 will affect the likelihood of another militarized interstate dispute in year $t .{ }^{11}$ Finally, we also control for system attributes that might be associated with conflict. First, we control for the number of states in each year of the system using the state list from the Correlates of War and second, the proportion of democratic states in each system year based on the number of states with a polity score greater than 7 as a fraction of the total number of states (Marshall, Jaggers, and Gurr 2010).

To test $\mathrm{H} 3$ the main explanatory variable is the natural log of Gross Domestic Product (GDP) produced in the power projecting state (that is, state $a$ ). We also control for the natural log of GDP in the target state (that is, state $b$ ), the CINC score in both the projecting state $a$ and the target state $b$, the polity score of state $a$ and target state $b$ and the number of states in the system. (GDP data were drawn from two sources: Madison [2012] for the model in Table 6a and Gleditsch [2002] for the model in Table 6b.)

\section{Model Specification}

To test $\mathrm{H} 1$ and $\mathrm{H} 2$, we use a negative binomial regression ( $\mathrm{H} 1$ : the frequency of MIDs occurring in a system year and H2: the frequency of MIDS occurring in a system year greater than a set distance). See King (1989) for a discussion of this choice in estimators for event data in international relations.

To test $\mathrm{H} 3$ we estimate a generalized estimation equation (GEE) on the dependent variable that measures the natural log of the distance between the projecting state's capital and the location of the MID for all MIDs. The GEE estimator accounts for multiple observations of the same dyad in the sample (Zorn 2001). A lagged dependent variable does not enter the equation since the model is estimated from independent MIDs and not time-series or panel data. Note that we estimated the GEE model with the errors clustered

(Fariss and Schnakenberg 2013; Schnakenberg and Fariss 2012; Treier and Jackman 2008). This research builds on insights from historical research on the development of diesel engines and gas turbines periods Smil (2007).

${ }^{11}$ Note that the shipping data from Lake (1999) begin in 1869 but the system level tests begin with the year 1870 because of the inclusion of lagged values of these variables. 
both around dispute-dyad and around the power projecting state. We report results only for the former specification but the results are robust to the latter.

As a an additional robustness test we also restrict the analysis to MIDs that do not occur between contiguous states. We report the results for the full set of MIDs because we believe that amassing power and projecting it through large domestic territories follows the logic of our argument. Ultimately however the results are similar in both sets of models. All of the analyses reported here were conducted in R ( $\mathrm{R} 2012$ ). The code and data are publicly available at a Dataverse archive (see the first note above).

RESULTS

\section{System Level Analysis (H1 and H2)}

Table 1 displays results from a negative binomial regression of the number of MIDs that occur within the international system each year using the two different variables measuring global shipping rates. We use the negative binomial regression model since it relaxes the assumption made by the Poisson estimator that the mean and variance of the count variable are equal (King 1989).

We now report the substantive effects of an increase in shipping costs. A change from one standard deviation below the mean value of the Tramp value (\$49.80) to one standard deviation above the mean $(\$ 163.60)$ changes the expected number of militarized interstates disputes from $12.1[8.7,16.4]$ to 4.4 [3.4, 5.5]. We find a similar substantive effect for Rail Cost shipping.

TABLE 1 Negative Binomial Regression of All MIDs

\begin{tabular}{|c|c|c|c|c|}
\hline & Estimate & Std. Error & $t$ value & $\operatorname{Pr}(>|t|)$ \\
\hline \multicolumn{5}{|l|}{ Model a: Tramp Shipping } \\
\hline Intercept & 4.2152 & 1.4841 & 2.84 & 0.0061 \\
\hline $\mathrm{MID}_{\mathrm{t}-1}$ & 0.0635 & 0.0080 & 7.96 & 0.0000 \\
\hline In Tramp Shipping ${ }_{t-1}$ & -0.8494 & 0.1848 & -4.60 & 0.0000 \\
\hline Industrialization $_{\mathrm{t}-1}$ & -0.0276 & 0.3221 & -0.09 & 0.9321 \\
\hline State Count in System & 0.0163 & 0.0175 & 0.93 & 0.3547 \\
\hline Percent Democracy in System & 1.1391 & 3.3335 & 0.34 & 0.7337 \\
\hline \multicolumn{5}{|l|}{ Model b: Rail Cost } \\
\hline (Intercept) & 0.8483 & 1.2253 & 0.69 & 0.4916 \\
\hline MID & 0.0711 & 0.0140 & 5.07 & 0.0000 \\
\hline Rail Cost $_{t-1}$ & -2.0593 & 0.8784 & -2.34 & 0.0226 \\
\hline Industrialization $_{\mathrm{t}-1}$ & 0.0144 & 0.3184 & 0.05 & 0.9642 \\
\hline State Count in System & 0.0039 & 0.0186 & 0.21 & 0.8324 \\
\hline Percent Democracy in System & 3.7748 & 4.0925 & 0.92 & 0.3602 \\
\hline
\end{tabular}

Note. Negative binomial regression of the number of militarized interstate disputes $\left(\mathrm{MID}_{\mathrm{t}}\right)$ in the international system from 1870-1936 (MaOz 2012). The shipping variables used in models $a$ and $b$ are taken from Lake (2009). The dependent variable includes all MIDs that occur within the international system each year and thus captures the frequency of the events as a function of global shipping costs. 
A change from one standard deviation below the mean value of the Rail Cost value $(\$ 0.04)$ to one standard deviation above the mean $(\$ 0.47)$ changes the expected number of militarized interstates disputes from 9.5 [6.1, 14.1] to 3.0 $[2.6,5.7]$. In both models, the cost of shipping is negatively associated with the frequency of MIDs in the system.

Next, we estimate a series of negative binomial regressions of the number of MIDs in the international system from 1870-1936 that occur greater than a specified distance from the projecting state's capital. First, note that the models displayed in Table 2 and Table 3 vary by the inclusion of the shipping variable: Tramp shipping cost in Table 2 and Rail cost in Table 3 respectively. Second, note that two lagged count variables are included in each of these models. The first lagged variable is the number of MIDs that occur close to the projecting state's capital in the previous year; that is, the number of MIDs that occurred at less than or equal to the distance cutoff from the projecting state's capital. The second lagged variable is the number of MIDs that occur far away in the previous year; that is, the number of MIDs that occurred past the distance cutoff. As expected, the cost of shipping reduces the number of MIDs that occur at a distance greater than either $1000 \mathrm{~km}$ (model a), 2000km (model b), 3000km (model c) or $5000 \mathrm{~km}$ (model d) from the projecting state's capital. A model of $4000 \mathrm{~km}$ is consistent with the results obtained using the $3000 \mathrm{~km}$ and $5000 \mathrm{~km}$ cutoffs for both shipping variables.

We now turn to a discussion of the substantive effects derived from these models. First, note that the expected values generated from these models are less than the expected values generated from the models displayed in Table 1. The lower expected values result from the exclusion of proximate MIDs; that is, the dependent variables in these models are counts of MIDs that occur at a considerable distance from the projecting state's capital. We examine the changes for the $2000 \mathrm{~km}$ model but the quantities are similar for each of the cutoffs. A change from one standard deviation below the mean value of the Tramp value (\$49.80) to one standard deviation above the mean $(\$ 163.60)$ changes the expected number of militarized interstates disputes from 5.3 [3.5, 7.8] to 2.1 [1.3, 3.1]. Similarly, for the Rail cost value from one standard deviation below the mean (\$0.04) to one standard deviation above the mean $(\$ 0.47)$ changes the expected number of militarized interstates disputes from 4.6 [3.1, 6.5] to 1.8 $[1.1,2.8]$.

Finally, we repeat the frequency analyses of distant MIDs on a subset of MIDs that occurred between noncontiguous states in order to ensure that results are not an artifact of large states projecting power at great distance within their borders. ${ }^{12}$ For this analysis, we simply exclude MIDs

\footnotetext{
${ }^{12}$ We only repeat the tests of $\mathrm{H} 2$ for the frequency of MIDs occurring in a system year greater than a set distance. We do not repeat the frequency analyses for $\mathrm{H} 1$ because we were interested in the total number of MIDs in the system each year for those tests.
} 
TABLE 2 Negative Binomial Regression of MIDs at Four Distances

\begin{tabular}{|c|c|c|c|c|}
\hline & Estimate & Std. Error & $t$ value & $\operatorname{Pr}(>|\mathrm{t}|)$ \\
\hline \multicolumn{5}{|l|}{ Model $a:>1000 k m$} \\
\hline Intercept & 3.8813 & 1.9201 & 2.02 & 0.0476 \\
\hline $\mathrm{MID}_{\mathrm{t}-1}>1000 \mathrm{~km}$ & 0.0403 & 0.0190 & 2.12 & 0.0384 \\
\hline $\mathrm{MID}_{\mathrm{t}-1} \leq 1000 \mathrm{~km}$ & 0.1462 & 0.0527 & 2.78 & 0.0073 \\
\hline ln Tramp Shipping ${ }_{t-1}$ & -0.8355 & 0.2260 & -3.70 & 0.0005 \\
\hline Industrialization $_{\mathrm{t}-1}$ & -0.0912 & 0.4106 & -0.22 & 0.8250 \\
\hline State Count in System & 0.0519 & 0.0172 & 3.01 & 0.0038 \\
\hline Percent Democracy in System & -6.2602 & 3.2403 & -1.93 & 0.0580 \\
\hline \multicolumn{5}{|l|}{ Model b: > 2000km } \\
\hline Intercept & 4.0740 & 2.1055 & 1.93 & 0.0576 \\
\hline $\mathrm{MID}_{\mathrm{t}-1}>2000 \mathrm{~km}$ & 0.0800 & 0.0237 & 3.38 & 0.0013 \\
\hline $\mathrm{MID}_{\mathrm{t}-1} \leq 2000 \mathrm{~km}$ & 0.0538 & 0.0118 & 4.56 & 0.0000 \\
\hline ln Tramp Shipping ${ }_{t-1}$ & -0.7773 & 0.2788 & -2.79 & 0.0071 \\
\hline Industrialization $_{\mathrm{t}-1}$ & -0.2846 & 0.4140 & -0.69 & 0.4944 \\
\hline State Count in System & 0.0243 & 0.0148 & 1.65 & 0.1051 \\
\hline Percent Democracy in System & -0.6454 & 2.7671 & -0.23 & 0.8164 \\
\hline \multicolumn{5}{|l|}{ Model c: > 3000km } \\
\hline Intercept & 3.0613 & 2.5995 & 1.18 & 0.2435 \\
\hline $\mathrm{MID}_{\mathrm{t}-1}>3000 \mathrm{~km}$ & 0.0978 & 0.0387 & 2.53 & 0.0140 \\
\hline $\mathrm{MID}_{\mathrm{t}-1} \leq 3000 \mathrm{~km}$ & 0.0434 & 0.0138 & 3.14 & 0.0026 \\
\hline ln Tramp Shipping ${ }_{t-1}$ & -0.5838 & 0.3466 & -1.68 & 0.0972 \\
\hline Industrialization $_{\mathrm{t}-1}$ & -0.2857 & 0.5325 & -0.54 & 0.5935 \\
\hline State Count in System & 0.0214 & 0.0231 & 0.93 & 0.3586 \\
\hline Percent Democracy in System & -0.6270 & 4.2523 & -0.15 & 0.8833 \\
\hline \multicolumn{5}{|l|}{ Model d: > 5000km } \\
\hline Intercept & 5.0326 & 4.1647 & 1.21 & 0.2316 \\
\hline $\mathrm{MID}_{\mathrm{t}-1}>5000 \mathrm{~km}$ & 0.1146 & 0.0617 & 1.86 & 0.0682 \\
\hline $\mathrm{MID}_{\mathrm{t}-1} \leq 5000 \mathrm{~km}$ & 0.0560 & 0.0196 & 2.85 & 0.0059 \\
\hline ln Tramp Shipping ${ }_{t-1}$ & -0.8533 & 0.4932 & -1.73 & 0.0886 \\
\hline Industrialization $_{\mathrm{t}-1}$ & -0.5976 & 0.8317 & -0.72 & 0.4752 \\
\hline State Count in System & 0.0164 & 0.0336 & 0.49 & 0.6285 \\
\hline Percent Democracy in System & 0.5034 & 6.3608 & 0.08 & 0.9372 \\
\hline
\end{tabular}

Note. Negative binomial regression of the number of militarized interstate disputes $\left(\mathrm{MID}_{\mathrm{t}}\right)$ in the international system from 1870-1936 that occur at the following distances: model a, greater than 1000km; model $b$, greater than $2000 \mathrm{~km}$; model c, greater than $3000 \mathrm{~km}$; model d, greater than $5000 \mathrm{~km}$ (Maoz 2012). Note that two lagged count variables are included in these models: the number of MIDs that occur close to the projecting state's capital and the number of MIDs that occur far away.

from the count dependent variables described above if the Correlates of War Project (2012) identified the disputants as contiguous within 400 miles (about 644km) (Gochman 1991; Stinnett, Tir, Schafer, Diel and Gochman 2002). The results from Table 2 and Table 3 are strengthened by these new models displayed in Table 4 and Table 5. The effect sizes of the shipping variables increase across the models. However, the tramp shipping variable is no longer nominally significant at cutoffs of $3000 \mathrm{~km}$ or greater. Again, a model of $4000 \mathrm{~km}$ is consistent with the results obtained using the $3000 \mathrm{~km}$ and $5000 \mathrm{~km}$ cutoffs for both shipping variables. 
TABLE 3 Negative Binomial Regression of MIDs at Four Distances

\begin{tabular}{|c|c|c|c|c|}
\hline & Estimate & Std. Error & $t$ value & $\operatorname{Pr}(>|t|)$ \\
\hline \multicolumn{5}{|l|}{ Model a: > 1000km } \\
\hline Intercept & 0.5887 & 1.7037 & 0.35 & 0.7310 \\
\hline $\mathrm{MID}_{\mathrm{t}-1}>1000 \mathrm{~km}$ & 0.0498 & 0.0247 & 2.02 & 0.0483 \\
\hline $\mathrm{MID}_{\mathrm{t}-1} \leq 1000 \mathrm{~km}$ & 0.1379 & 0.0582 & 2.37 & 0.0213 \\
\hline Rail Cost $_{t-1}$ & -1.9236 & 0.8273 & -2.33 & 0.0237 \\
\hline Industrialization $_{\mathrm{t}-1}$ & -0.0425 & 0.4560 & -0.09 & 0.9261 \\
\hline State Count in System & 0.0365 & 0.0164 & 2.22 & 0.0302 \\
\hline Percent Democracy in System & -3.1793 & 3.5805 & -0.89 & 0.3784 \\
\hline \multicolumn{5}{|l|}{ Model b: > 2000km } \\
\hline Intercept & 1.3116 & 1.5995 & 0.82 & 0.4157 \\
\hline $\mathrm{MID}_{\mathrm{t}-1}>2000 \mathrm{~km}$ & 0.1158 & 0.0394 & 2.94 & 0.0048 \\
\hline $\mathrm{MID}_{\mathrm{t}-1} \leq 2000 \mathrm{~km}$ & 0.0422 & 0.0344 & 1.23 & 0.2253 \\
\hline Rail Cost $t_{t-1}$ & -2.1959 & 0.7620 & -2.88 & 0.0056 \\
\hline Industrialization $_{\mathrm{t}-1}$ & -0.3039 & 0.4322 & -0.70 & 0.4849 \\
\hline State Count in System & 0.0045 & 0.0156 & 0.29 & 0.7725 \\
\hline Percent Democracy in System & 3.5354 & 3.5844 & 0.99 & 0.3282 \\
\hline \multicolumn{5}{|l|}{ Model c: > 3000km } \\
\hline Intercept & 1.1985 & 2.1266 & 0.56 & 0.5753 \\
\hline $\mathrm{MID}_{\mathrm{t}-1}>3000 \mathrm{~km}$ & 0.1558 & 0.0605 & 2.57 & 0.0127 \\
\hline $\mathrm{MID}_{\mathrm{t}-1} \leq 3000 \mathrm{~km}$ & 0.0401 & 0.0240 & 1.67 & 0.0999 \\
\hline Rail Cost $_{t-1}$ & -2.2424 & 1.0514 & -2.13 & 0.0373 \\
\hline Industrialization $_{\mathrm{t}-1}$ & -0.3665 & 0.5774 & -0.63 & 0.5282 \\
\hline State Count in System & 0.0049 & 0.0214 & 0.23 & 0.8201 \\
\hline Percent Democracy in System & 3.4841 & 5.2548 & 0.66 & 0.5100 \\
\hline \multicolumn{5}{|l|}{ Model d: > 5000km } \\
\hline Intercept & 2.7788 & 3.6004 & 0.77 & 0.4435 \\
\hline $\mathrm{MID}_{\mathrm{t}-1}>5000 \mathrm{~km}$ & 0.1987 & 0.0819 & 2.43 & 0.0185 \\
\hline $\mathrm{MID}_{\mathrm{t}-1} \leq 5000 \mathrm{~km}$ & 0.0585 & 0.0286 & 2.05 & 0.0453 \\
\hline Rail Cost $_{t-1}$ & -3.5071 & 1.4448 & -2.43 & 0.0184 \\
\hline Industrialization $_{\mathrm{t}-1}$ & -0.8502 & 0.9921 & -0.86 & 0.3951 \\
\hline State Count in System & -0.0072 & 0.0334 & -0.22 & 0.8293 \\
\hline Percent Democracy in System & 6.9816 & 7.8169 & 0.89 & 0.3756 \\
\hline
\end{tabular}

Note. Negative binomial regression of the number of militarized interstate disputes $\left(\mathrm{MID}_{\mathrm{t}}\right)$ in the international system from 1870-1936 that occur at the following distances: model $a$, greater than $1000 \mathrm{~km}$; model b, greater than $2000 \mathrm{~km}$; model c, greater than $3000 \mathrm{~km} ;$ model $d$, greater than $5000 \mathrm{~km}$ (MaOz 2012).

\section{Dispute Level Analysis (H3)}

Recall that our expectation for $\mathrm{H} 3$ is that states with greater relative economic resources will participate in MIDs at greater distances from their capital city than states with less economic resources in the sample of all MID participants. We estimate a GEE model on all MIDs (1870-2000) and on more recent MIDs (1950-2000). The time periods are determined by the coverage of the two data sources for GDP. The data available from Madison (2012) begin in 1870 and the data available from Gleditsch (2002) begin in 1950 (see Table 6). 
TABLE 4 Negative Binomial Regression of MIDs at Four Distances

\begin{tabular}{|c|c|c|c|c|}
\hline & Estimate & Std. Error & $t$ value & $\operatorname{Pr}(>|t|)$ \\
\hline \multicolumn{5}{|l|}{ Model a: > 1000km } \\
\hline Intercept & 4.5219 & 3.6237 & 1.25 & 0.2168 \\
\hline $\mathrm{MID}_{\mathrm{t}-1}>1000 \mathrm{~km}$ & 0.0931 & 0.0422 & 2.20 & 0.0313 \\
\hline $\mathrm{MID}_{\mathrm{t}-1} \leq 1000 \mathrm{~km}$ & 0.2426 & 0.1410 & 1.72 & 0.0905 \\
\hline ln Tramp Shipping ${ }_{\mathrm{t}-1}$ & -1.1249 & 0.3711 & -3.03 & 0.0036 \\
\hline Industrialization $_{\mathrm{t}-1}$ & -0.1564 & 0.7660 & -0.20 & 0.8389 \\
\hline State Count in System & 0.0030 & 0.0368 & 0.08 & 0.9363 \\
\hline Percent Democracy in System & 7.2738 & 6.3399 & 1.15 & 0.2557 \\
\hline \multicolumn{5}{|l|}{ Model b: > 2000km } \\
\hline Intercept & 5.3603 & 3.4621 & 1.55 & 0.1267 \\
\hline $\mathrm{MID}_{\mathrm{t}-1}>2000 \mathrm{~km}$ & 0.1251 & 0.0437 & 2.86 & 0.0058 \\
\hline $\mathrm{MID}_{\mathrm{t}-1} \leq 2000 \mathrm{~km}$ & 0.1187 & 0.0281 & 4.22 & 0.0001 \\
\hline ln Tramp Shipping $\mathrm{t}_{-1}$ & -1.1163 & 0.4148 & -2.69 & 0.0092 \\
\hline Industrialization $_{\mathrm{t}-1}$ & -0.4426 & 0.6570 & -0.67 & 0.5031 \\
\hline State Count in System & 0.0126 & 0.0251 & 0.50 & 0.6187 \\
\hline Percent Democracy in System & 4.0487 & 4.7525 & 0.85 & 0.3976 \\
\hline \multicolumn{5}{|l|}{ Model c: > 3000km } \\
\hline Intercept & 2.9476 & 5.2488 & 0.56 & 0.5765 \\
\hline $\mathrm{MID}_{\mathrm{t}-1}>3000 \mathrm{~km}$ & 0.1152 & 0.0685 & 1.68 & 0.0977 \\
\hline $\mathrm{MID}_{\mathrm{t}-1} \leq 3000 \mathrm{~km}$ & 0.0952 & 0.0274 & 3.48 & 0.0009 \\
\hline ln Tramp Shipping ${ }_{\mathrm{t}-1}$ & -0.7906 & 0.5181 & -1.53 & 0.1322 \\
\hline Industrialization $_{t-1}$ & -0.1201 & 1.0951 & -0.11 & 0.9131 \\
\hline State Count in System & 0.0090 & 0.0287 & 0.31 & 0.7550 \\
\hline Percent Democracy in System & 2.2085 & 6.7865 & 0.33 & 0.7460 \\
\hline \multicolumn{5}{|l|}{ Model d: > 5000km } \\
\hline Intercept & 6.9076 & 6.0177 & 1.15 & 0.2555 \\
\hline $\mathrm{MID}_{\mathrm{t}-1}>5000 \mathrm{~km}$ & 0.1349 & 0.0902 & 1.50 & 0.1399 \\
\hline $\mathrm{MID}_{\mathrm{t}-1} \leq 5000 \mathrm{~km}$ & 0.0912 & 0.0371 & 2.46 & 0.0169 \\
\hline ln Tramp Shipping $\mathrm{t}_{-1}$ & -0.9949 & 0.5961 & -1.67 & 0.1002 \\
\hline Industrialization $_{\mathrm{t}-1}$ & -0.6609 & 1.2596 & -0.52 & 0.6017 \\
\hline State Count in System & -0.0526 & 0.0396 & -1.33 & 0.1894 \\
\hline Percent Democracy in System & 10.3191 & 8.5439 & 1.21 & 0.2318 \\
\hline
\end{tabular}

Note. Negative binomial regression of the number of militarized interstate disputes $\left(\mathrm{MID}_{\mathrm{t}}\right)$ in the international system from 1870-1936 that occur at the following distances: model a, greater than 1000km; model $b$, greater than $2000 \mathrm{~km}$; model c, greater than $3000 \mathrm{~km}$; model $d$, greater than $5000 \mathrm{~km}$ (Maoz 2012). The MID counts do not include conflicts that occurred between contiguous states as defined by the Correlates of War Project (2012).

In both samples, we find that an increase in GDP leads to an increase in the expected distance of the MID from the projecting state's capital. In the model of the full sample of years (1870-2000), we find that a change from the 25 th percentile of the project state $a$ 's GDP to the 75 th percentile of GDP increases the expected distance of a MID from the projecting state $a$ 's capital from $1366 \mathrm{~km}$ [1210km, $1548 \mathrm{~km}$ ] to $2675 \mathrm{~km}$ [2394km, 2966km]. A difference of $1309 \mathrm{~km}[1184 \mathrm{~km}, 1418 \mathrm{~km}]$.

In the model of the larger sample of MIDs (1950-2000), we find that a change from the 25 th percentile of the project state $a$ 's GDP to the 75 th percentile of GDP increases the expected distance of a MID from the projecting 
TABLE 5 Negative Binomial Regression of MIDs at Four Distances

\begin{tabular}{|c|c|c|c|c|}
\hline & Estimate & Std. Error & $t$ value & $\operatorname{Pr}(>|\mathrm{t}|)$ \\
\hline \multicolumn{5}{|l|}{ Model a: > 1000km } \\
\hline Intercept & 1.0976 & 2.5218 & 0.44 & 0.6651 \\
\hline $\mathrm{MID}_{\mathrm{t}-1}>1000 \mathrm{~km}$ & 0.1288 & 0.0569 & 2.26 & 0.0276 \\
\hline $\mathrm{MID}_{\mathrm{t}-1} \leq 1000 \mathrm{~km}$ & 0.6414 & 0.9461 & 0.68 & 0.5006 \\
\hline Rail Cost $_{t-1}$ & -3.5590 & 1.1895 & -2.99 & 0.0041 \\
\hline Industrialization $_{\mathrm{t}-1}$ & -0.3232 & 0.6912 & -0.47 & 0.6419 \\
\hline State Count in System & -0.0285 & 0.0383 & -0.75 & 0.4589 \\
\hline Percent Democracy in System & 14.3378 & 7.9573 & 1.80 & 0.0770 \\
\hline \multicolumn{5}{|l|}{ Model b: > 2000km } \\
\hline Intercept & 1.9235 & 2.3279 & 0.83 & 0.4121 \\
\hline $\mathrm{MID}_{\mathrm{t}-1}>2000 \mathrm{~km}$ & 0.1904 & 0.0675 & 2.82 & 0.0067 \\
\hline $\mathrm{MID}_{\mathrm{t}-1} \leq 2000 \mathrm{~km}$ & 0.1082 & 0.1022 & 1.06 & 0.2945 \\
\hline Rail Cost $t_{t-1}$ & -3.4835 & 1.1133 & -3.13 & 0.0028 \\
\hline Industrialization $_{\mathrm{t}-1}$ & -0.5966 & 0.6397 & -0.93 & 0.3550 \\
\hline State Count in System & -0.0222 & 0.0301 & -0.74 & 0.4644 \\
\hline Percent Democracy in System & 11.6826 & 6.7944 & 1.72 & 0.0911 \\
\hline \multicolumn{5}{|l|}{ Model c: > 3000km } \\
\hline Intercept & 0.9503 & 4.0186 & 0.24 & 0.8139 \\
\hline $\mathrm{MID}_{\mathrm{t}-1}>3000 \mathrm{~km}$ & 0.1644 & 0.0966 & 1.70 & 0.0943 \\
\hline $\mathrm{MID}_{\mathrm{t}-1} \leq 3000 \mathrm{~km}$ & 0.1572 & 0.0474 & 3.31 & 0.0016 \\
\hline Rail Cost $_{t-1}$ & -3.1035 & 1.3150 & -2.36 & 0.0218 \\
\hline Industrialization $_{\mathrm{t}-1}$ & -0.3181 & 1.1241 & -0.28 & 0.7783 \\
\hline State Count in System & -0.0211 & 0.0346 & -0.61 & 0.5435 \\
\hline Percent Democracy in System & 8.9508 & 8.8560 & 1.01 & 0.3165 \\
\hline \multicolumn{5}{|l|}{ Model d: > 5000km } \\
\hline Intercept & 5.9212 & 4.7682 & 1.24 & 0.2195 \\
\hline $\mathrm{MID}_{\mathrm{t}-1}>1000 \mathrm{~km}$ & 0.2065 & 0.1234 & 1.67 & 0.0998 \\
\hline $\mathrm{MID}_{\mathrm{t}-1} \leq 5000 \mathrm{~km}$ & 0.2182 & 0.0808 & 2.70 & 0.0091 \\
\hline Rail Cost $_{t-1}$ & -5.8587 & 1.8444 & -3.18 & 0.0024 \\
\hline Industrialization $_{\mathrm{t}-1}$ & -1.2595 & 1.3441 & -0.94 & 0.3528 \\
\hline State Count in System & -0.1020 & 0.0461 & -2.21 & 0.0310 \\
\hline Percent Democracy in System & 22.4015 & 11.0802 & 2.02 & 0.0480 \\
\hline
\end{tabular}

Note. Negative binomial regression of the number of militarized interstate disputes $\left(\mathrm{MID}_{\mathrm{t}}\right)$ in the international system from 1870-1936 that occur at the following distances: model a, greater than 1000km; model $b$, greater than $2000 \mathrm{~km}$; model c, greater than $3000 \mathrm{~km}$; model $d$, greater than $5000 \mathrm{~km}$ (Maoz 2012). The MID counts do not include conflicts that occurred between contiguous states as defined by the Correlates of War Project (2012).

state $a$ 's capital from $1033 \mathrm{~km}$ [919km, $1165 \mathrm{~km}]$ to $2629 \mathrm{~km}[2354 \mathrm{~km}, 2939 \mathrm{~km}]$. A difference of $1596 \mathrm{~km}[1436 \mathrm{~km}, 1774 \mathrm{~km}] .^{13}$

Again, we repeat these analyses on a subset of MIDs that occurred between noncontiguous states in order to ensure the results are not an artifact of large states projecting power at great distance within their borders.

\footnotetext{
${ }^{13}$ We estimated these models without dyads that contained the United States since this state projects power in many dyadic disputes during the time period of our analysis. The results are robust to the exclusion of these dyads.
} 
TABLE 6 Generalized Estimation Equation of $\ln$ Distance to MID $_{\mathrm{a}}$

\begin{tabular}{|c|c|c|c|c|c|}
\hline & Estimate & Naive S.E. & Naive $z$ & Robust S.E. & Robust $z$ \\
\hline \multicolumn{6}{|l|}{ Model a: $1870-2000$} \\
\hline Intercept & 2.640 & 0.169 & 15.609 & 0.271 & 9.726 \\
\hline ln distance to $\mathrm{MID}_{\mathrm{b}}$ & 0.470 & 0.016 & 30.155 & 0.026 & 18.197 \\
\hline $\ln \mathrm{GDP}_{\mathrm{t}-1, \mathrm{a}}$ & -0.088 & 0.016 & -5.537 & 0.026 & -3.431 \\
\hline $\ln \mathrm{GDP}_{\mathrm{t}-1, \mathrm{a}}$ & 0.232 & 0.014 & 16.505 & 0.021 & 11.191 \\
\hline $\mathrm{CINC}_{\mathrm{t}-1, \mathrm{~b}}$ & 6.801 & 0.717 & 9.484 & 1.251 & 5.436 \\
\hline $\mathrm{CINC}_{\mathrm{t}-1, \mathrm{a}}$ & 2.050 & 0.402 & 5.103 & 0.594 & 3.450 \\
\hline State Count in System & -0.001 & 0.000 & -2.322 & 0.001 & -1.700 \\
\hline Polity $2_{\mathrm{t}-1, \mathrm{~b}}$ & -0.017 & 0.003 & -6.845 & 0.003 & -5.042 \\
\hline Polity $2_{\mathrm{t}-1, \mathrm{a}}$ & 0.007 & 0.003 & 2.974 & 0.004 & 1.850 \\
\hline \multicolumn{6}{|l|}{ Model b: 1950-2000 } \\
\hline Intercept & 6.459 & 0.507 & 12.749 & 0.642 & 10.060 \\
\hline In distance to $\mathrm{MID}_{\mathrm{b}}$ & 0.129 & 0.022 & 5.835 & 0.031 & 4.156 \\
\hline $\ln \mathrm{GDP}_{\mathrm{t}-1, \mathrm{~b}}$ & -0.054 & 0.024 & -2.235 & 0.037 & -1.449 \\
\hline $\ln \mathrm{GDP}_{\mathrm{t}-1, \mathrm{a}}$ & 0.129 & 0.024 & 5.375 & 0.028 & 4.659 \\
\hline $\mathrm{CINC}_{\mathrm{t}-1, \mathrm{~b}}$ & 4.879 & 1.008 & 4.840 & 1.406 & 3.470 \\
\hline $\mathrm{CINC}_{\mathrm{t}-1, \mathrm{a}}$ & 0.715 & 0.465 & 1.536 & 0.552 & 1.294 \\
\hline State Count in System & -0.005 & 0.001 & -5.668 & 0.001 & -4.079 \\
\hline Polity $2_{\mathrm{t}-1, \mathrm{~b}}$ & -0.012 & 0.005 & -2.446 & 0.007 & -1.711 \\
\hline Polity $2_{\mathrm{t}-1, \mathrm{a}}$ & 0.021 & 0.005 & 4.499 & 0.006 & 3.237 \\
\hline
\end{tabular}

Note. Generalized estimation equation of the distance from the capital of the power projecting state $a$ to the location of the militarized interstates dispute. GDP data were drawn from Madison (2012) for model $a$ and from Gleditsch (2002) for model $b$. These models include all dispute dyads.

As before, we exclude MIDs from the distance dependent variable if the disputants are in a contiguous dyad (Correlates of War Project 2012). These alternative models are displayed in Table 7 and consistent with those in Table 6. The coefficient on state $a$ 's GDP is smaller in these models but the substantive differences are consistent for the 1870-2000 model and actually increase for the 1950-2000 model. In the model of the larger sample of MIDs (1870-2000), a change from the 25th percentile of the project state $a$ 's GDP to the 75 th percentile of GDP increases the expected distance of a MID from the projecting state $a$ 's capital from $4742 \mathrm{~km}[3957 \mathrm{~km}, 5711 \mathrm{~km}]$ to $6099 \mathrm{~km}[5360 \mathrm{~km}, 6907 \mathrm{~km}]$. A difference of $1357 \mathrm{~km}$ [1196km, $1403 \mathrm{~km}]$. In the model of the more recent sample of MIDs (1950-2000), a change from the 25 th percentile of the project state $a$ 's GDP to the 75th percentile of GDP increases the expected distance of a MID from the projecting state $a$ 's capital from $3705 \mathrm{~km}[3205 \mathrm{~km}, 4538 \mathrm{~km}$ ] to 5657 [4921km, $6538 \mathrm{~km}$ ]. A difference of $1952 \mathrm{~km}[1895 \mathrm{~km}, 2000 \mathrm{~km}]$

These results have implications for China, India, and Brazil as they move from the 75th percentile to the 95th percentile of GDP. The models suggest that these states may become more likely to project power globally rather then just regionally. Considering just the model based on disputes from 1950 to 2000, moving from the 75th percentile to 95th percentile GDP increases the expected distance of a MID from the projecting state $a$ 's capital 
TABLE 7 Generalized Estimation Equation of ln Distance to MID

\begin{tabular}{|c|c|c|c|c|c|}
\hline & Estimate & Naive S.E. & Naive $\mathrm{z}$ & Robust S.E. & Robust z \\
\hline \multicolumn{6}{|l|}{ Model a: $1870-2000$} \\
\hline Intercept & 5.819 & 0.299 & 19.486 & 0.388 & 14.992 \\
\hline In distance to $\mathrm{MID}_{\mathrm{b}}$ & 0.177 & 0.022 & 7.967 & 0.031 & 5.713 \\
\hline $\ln \mathrm{GDP}_{\mathrm{t}-\mathrm{b}}$ & 0.023 & 0.024 & 0.968 & 0.035 & 0.658 \\
\hline $\ln \operatorname{GDP}_{\mathrm{t} 1, \mathrm{a}}$ & 0.087 & 0.023 & 3.817 & 0.030 & 2.940 \\
\hline $\mathrm{CINC}_{\mathrm{t}-1, \mathrm{~b}}$ & 2.308 & 0.809 & 2.854 & 1.219 & 1.893 \\
\hline $\mathrm{CINC}_{\mathrm{t}-1, \mathrm{a}}$ & 1.271 & 0.455 & 2.794 & 0.539 & 2.358 \\
\hline State Count in System & -0.001 & 0.001 & -0.805 & 0.001 & -0.526 \\
\hline Polity $2_{\mathrm{t}-1, \mathrm{~b}}$ & -0.015 & 0.004 & -3.639 & 0.006 & -2.700 \\
\hline Polity $2_{\mathrm{t}-1, \mathrm{a}}$ & 0.013 & 0.005 & 2.757 & 0.008 & 1.584 \\
\hline \multicolumn{6}{|l|}{ Model b: $1950-2000$} \\
\hline Intercept & 1.736 & 0.291 & 5.963 & 0.479 & 3.622 \\
\hline ln distance to $\mathrm{MID}_{\mathrm{b}}$ & 0.479 & 0.016 & 29.074 & 0.029 & 16.810 \\
\hline $\ln \mathrm{GDP}_{\mathrm{t}-1, \mathrm{~b}}$ & -0.136 & 0.016 & -8.470 & 0.026 & -5.174 \\
\hline $\ln \mathrm{GDP}_{\mathrm{t}-1, \mathrm{a}}$ & 0.288 & 0.015 & 19.697 & 0.021 & 13.891 \\
\hline $\mathrm{CINC}_{\mathrm{t}-1, \mathrm{~b}}$ & 7.488 & 0.903 & 8.288 & 1.267 & 5.910 \\
\hline $\mathrm{CINC}_{\mathrm{t}-1, \mathrm{a}}$ & 1.944 & 0.423 & 4.600 & 0.669 & 2.905 \\
\hline State Count in System & -0.004 & 0.001 & -6.359 & 0.001 & -4.273 \\
\hline Polity $2_{\mathrm{t}-1, \mathrm{~b}}$ & -0.022 & 0.003 & -8.136 & 0.004 & -6.007 \\
\hline Polity $2_{\mathrm{t}-1, \mathrm{a}}$ & 0.010 & 0.003 & 3.976 & 0.004 & 2.531 \\
\hline
\end{tabular}

Note. Generalized estimation equation of the distance from the capital of the power projecting state $a$ to the location of the militarized interstates dispute. GDP data were drawn from Madison (2012) for model $a$ and from Gleditsch (2002) for model $b$. These models do not include dyads that are contiguous as defined by the Correlates of War Project (2012).

from $2629 \mathrm{~km}$ [2318km, 2965km] to $4424 \mathrm{~km}[3783 \mathrm{~km}, 5267 \mathrm{~km}]$. A difference of $1795 \mathrm{~km}[1465 \mathrm{~km}, 2302 \mathrm{~km}]$.

\section{Summary of Results}

Despite an abundance of system-level theories about how the distribution and use of power affects state behavior, few empirical analyses of this phenomenon have been performed. The models developed in this paper provide evidence of how system level variables, like the cost of projecting power affect state behavior regarding the application of military power. When the cost of projecting power declines states project power with higher frequency and at greater distances. However, our results should be interpreted with caution as they utilize data from a limited time period and do not take demand side variables into consideration.

\section{CONCLUSION}

The goal of this paper was to establish the relationship between power projection, technology, and economic power. The results provide empirical 
support for the hypotheses we test. We find that as technology decreases the cost of projecting power, more states deploy their military forces within the system. Our results also suggest that as states become economically powerful they tend to project power at greater distances and with greater frequency. Rather than competing, these hypotheses complement one another as more economically powerful states are likely better able to afford the technologies that reduce the cost of projecting power. These empirical relationships have implications for international relations in the twenty-first century, as a number of states have experienced tremendous economic growth.

Today we are witnessing a renegotiating of regional orders as the economic power of states such as China and India increases. Such renegotiations are based largely on changes in the relative ability of these states to project power and the limit of the power projection capabilities of geographically distant countries like the United States. The shape of future regional orders and even the international system depends in part on the relative ability of these rising states to project power. States that project power globally may enact more hierarchical relationships with the states that exist within their order. This, of course, does not mean that states that have the capability to project power will attempt to create such relationships, only that they can. The ability of states to project power acts as a constraint on the types of behaviors and relationships such states can engage in. Because these behaviors and hierarchical relationships are so central to the study of international relations, it is important to understand what factors condition and constrain the choices of actors to engage in power projection over other forms of influence.

Our results have additional implications for how military technological innovation may affect the nature of the projection of military force and number of actors that can exercise coercive military influence globally. Military technological innovation is producing a new set of platforms such as unmanned vehicles, and inexpensive conventional precision guided ballistic and cruise missiles, and improved C4ISR ${ }^{14}$ If these new technologies, as they diffuse to a wider set of actors, reduce the cost of projecting power, then our results suggest that we may observe states engaging in disputes at greater distances. Conversely, if the diffusion of such technologies increases the cost of projecting power then we may observe fewer states projecting power and therefore fewer coercive interactions.

In future research we attempt to expand the temporal scope of this study and incorporate demand side variables into the analysis of state-level behaviors and measure additional geographic information relevant to power projection globally and regionally. More broadly, we hope that our research inspires more analysis of why some economically powerful states choose to project power while others do not.

${ }^{14}$ This is a military acronym for "command, control, communications, computers, intelligence, surveillance, and reconnaissance." 


\section{REFERENCES}

Aleprete, Michael E. Jr., and Aaron M. Hoffman. (2012) The Strategic Development of Border Areas: Explaining Variation in Interaction Opportunity across Land Borders. International Interactions 38(1):1-28.

Bean, Richard. (1973) War and the Birth of the Nation State. The Journal of Economic History 33(1):220.

Blechman, Barry M., and Stephen S. Kaplan. (1978) Force Without War. U.S. Armed Forces as a Political Instrument. Washington, DC: Brookings Institution.

Boulding, Kenneth E. (1962) Conflict and Defense: A General Theory. New York: Harper and Row.

Braithwaite, Alex. (2006) The Geographic Spread of Militarized Disputes. Journal of Peace Research 43(5):507-522.

Braithwaite, Alex. (2010) Midloc: Introducing the Militarized Interstate Dispute Location Dataset. Journal of Peace Research 47(1):91-98.

Braithwaite, Alex. (2013) Mid location, 1816-2001 (v1.0).

Bueno de Mesquita, Bruce. (1981) The War Trap. New Haven, CT: Yale University Press.

Buhaug, Halvard, and Nils Petter Gleditsch. (2006) The Death of Distance? The Globalization of Armed Conflict. In Territoriality and Conflict in an Era of Globalization, edited by Miles Kahler and Barbara F. Walter. Cambridge: Cambridge University Press.

Correlates of War Project. (2012) Direct Contiguity Data, 1816-2006. version 3.1. Available at http://correlatesofwar.org.

Dudley, Leonard M. (1991) The Word and The Sword: How Techniques of Information and Violence Have Shaped Our World. Cambridge, MA: Blackwell.

Enterline, Andrew J. (1998) Regime Changes, Neighborhoods, and Interstate Conflict, 1816-1992. Journal of Conflict Resolution 42(6):804-829.

Fariss, Christopher J., and Keith E. Schnakenberg. (Forthcoming) Measuring Mutual Dependence Between State Repressive Actions. Journal of Conflict Resolution.

Farewell, Byron. (1972) Queen Victoria's Little Wars. London: Norton and Company.

Fearon, James D. (1995) Rationalist Explanations for War. International Organization, 49(3):379-414.

Gartzke, Erik. (1999) War Is in the Error Term. International Organization, 53(3): 567-587.

Gartzke, Erik. (2009) The Relevance of Power in International Relations. Working Paper San Diego. University of California.

Gartzke, Erik, and Dominic Rohner. (2011) The Political Economy of Imperialism, Decolonization, and Development. British Journal of Political Science 41(3): $525-556$.

Gleditsch, Kristian Skrede. (2002) Expanded Trade and GDP Data. Journal of Conflict Resolution 46(5):712-724.

Gleditsch, Kristian Skrede. (2013) Distance Between Capital Cities. Available at http://privatewww.essex.ac.uk/ ksg/data-5.html (accessed March 11, 2013).

Gleditsch, Kristian Skrede, and Michael D. Ward. (2001) Measuring Space: A Minimum-distance Database and Applications to International Studies. Journal of Peace Research 38(6):739-758. 
Gleditsch, Nils Petter. (1995) Geography, Democracy, and Peace. International Interactions 20(4):297-323.

Gochman, Charles S. (1991) Interstate Metrics: Conceptualizing, Operationalizing, and Measuring the Geographic Proximity of States Since the Congress of Vienna. International Interactions 17(1):93-112.

Hegre, Håvard. (2008) Gravitating Toward War Preponderance May Pacify, But Power Kills. Journal of Conflict Resolution 52(4):566-589.

Huth, Paul, and Bruce M. Russett. (1984) What Makes Deterrence Work: Cases from 1900 to 1980. World Politics 36(4):496-526.

Kennedy, Paul M. (1989) Rise and Fall of the Great Powers: Economic Change and Military Conflict from 1500 to 2000. New York: Random House.

King, Gary. (1989) Event Count Models for International Relations: Generalizations and Applications. International Studies Quarterly 33(2):123-147.

Lake, David A. (1992) Powerful Pacifists: Democratic States and War. American Political Science Review 86(1):24-37.

Lake, David A. (1999) Entangling Relations: American Foreign Relations in Its Century. Princeton, NJ: Princeton University Press.

Lake, David A. (2009) Hierarchy In International Relations. Ithaca, NY: Cornell University Press.

Lake, David A., and Angela O'Mahony. (2006) Territory and War: State Size and Patterns of Interstate Conflict. In Territoriality and Conflict in an Era of Globalization, edited by Miles Kahler and Barbara F. Walter. Cambridge: Cambridge University Press.

Lemke, Douglas. (1995) The Tyranny of Distance: Redefining Relevant Dyads. International Interactions 21(1):23-38.

Madison, Angus. (2012) Statistics on World Population, GDP and Per Capita GDP, 1-2008 AD. Available at http://www.ggdc.net/maddison/maddison-project/data. htm (accessed March 11, 2013).

Mahan, Alfred. (1890) The Influence of Seapower Upon History. Boston, MA: LittleBrown and Company.

Maoz, Zeev. (2012) Dyadic Mid Dataset (version 2.0). Available at http://psfaculty. ucdavis.edu/zmoaz/datasets.htm (accessed March 11, 2013).

Marshall, Monty, Keith Jaggers, and Ted R. Gurr. (2010) Polity IV Project: Political Regime Characteristics and Transitions 1800-2010 Dataset Users' Manual. Available at http://www.systemicpeace.org/polity/polity4.htm (accessed March 11, 2013).

Mearshemier, John J. (2001) The Tragedy of Great Power Politics. New York, NY: Norton and Company.

Meernik, James D. (1994) Presidential Decision Making and the Political Use of Military Force. International Studies Quarterly 38(1):121-138.

Meernik, James D. (2008) A Supply and Demand Theory of US Military Policy. Conflict Management and Peace Science 25(1):33-48.

Modelski, George. (1987) Long Cycles in World Politics. Seattle: University of Washington Press.

Modelski, George, and William R. Thompson. (1988) Sea Power in Global Politics, 1494-1993. Seattle, WA: University of Washington Press. 
Most, Benjamin A., and Harvey Starr. (1980) Diffusion, Reinforcement, Geopolitics, and the Spread of War. American Political Science Review, 74(4):932-946.

Most, Benjamin A., and Harvey Starr. (1989) Inquiry, Logic, and International Politics. Columbia: University of South Carolina Press.

O'Laughlin, John. (1987) Spatial Models of International Conflicts: Extending Current Theories of War Behavior. Annals of the Association of American Geographers 76(1):62-80.

Olson, Mancur. (1993) Dictatorship, Democracy, and Development. American Political Science Review 87(3):567-576.

Olson, Mancur. (2000) Power and Prosperity: Outgrowing Communist and Capitalist Dictatorships. Oxford: Oxford University Press.

Posen, Barry R. (2003) Command of the Commons: The Military Foundation of U.S. Hegemony. International Security 28(1):5-46.

Pugh, Philip. (1986) The Cost of Sea Power: The Influence of Money on Naval Affairs from 1815 to the Present Day. London: Conway Maritime Press.

Quester, George H. (1977) Offense and Defense in the International System. New York: John Wiley \& Sons.

R Development Core Team. (2011) R: A Language and Environment for Statistical Computing. Vienna: R Foundation for Statistical Computing.

Russett, Bruce, and John R. Oneal. (2001) Triangulating Peace: Democracy, Interdependence, and International Organizations. New York: Norton.

Schnakenberg, Keith E., and Christopher J. Fariss. (2012) Dynamic Patterns of Human Rights Practices. Working Paper. Available at http://ssrn.com/abstract $=1534335$.

Scott, James C. (2009) The Art of Not Being Governed: An Anarchist History of Upland Southeast Asia. New Haven, CT: Yale University Press.

Senese, Paul D. (2005) Territory, Contiguity, and International Conflict: Assessing a New Joint Explanation. American Journal of Political Science 49(4):769-779.

Singer, J. David. (1987) Reconstructing the Correlates of War Dataset on Material Capabilities of States, 1816-1985. International Interactions 14(2):115-132.

Siverson, Randolph M., and Harvey Starr. (1990) Opportunity, Willingness, and the Diffusion of war. The American Political Science Review 84(1):47-67.

Smil, Vaclav. (2007) The Two Prime Movers of Globalization: History and Impact of Diesel Engines and Gas Turbines. Journal of Global History 2:373-394.

Starr, Harvey. (2002) The "Nature" of Contiguous Borders: Ease of Interaction, Salience, and the Analysis of Crisis. International Interactions 28(3):213-235.

Starr, Harvey, and Benjamin A. Most. (1976) The Substance and Study of Borders in International Relations Research. International Studies Quarterly 20(4):581-620.

Starr, Harvey, and G. Dale Thomas. (2005) The Nature of Borders and International Conflict: Revisiting Hypotheses on Territory. International Studies Quarterly 49(1):123-139.

Stinnett, Douglas M., Jaroslav Tir, Philip Schafer, Paul F. Diehl, and Charles Gochman. (2002) The Correlates of War Project Direct Contiguity Data. Version 3. Conflict Management and Peace Science 19(2):58-66.

Tilly, Charles. (1992) Coercion, Capital, and European States. Cambridge, MA: Blackwell.

Treier, Shawn, and Simon Jackman. (2008) Democracy as a Latent Variable. American Journal of Political Science 52(1):201-217. 
Tullock, Gordon. (1980) Rent-Seeking as a Zero-sum Game. In Toward a Theory of the Rent-Seeking Society, edited by James M. Buchanan, Robert D. Tollison, and Gordon Tullock. College Station: Texas AM University Press.

Vasquez, John A. (1995) Why Do Neighbors Fight: Proximity, Interaction, or Territorialy. Journal of Peace Research 32(3):277-293.

Zorn, Christopher. (2001) Generalized Estimating Equation Models for Correlated Data: A Review with Applications. American Journal of Political Science 45(2):470-490. 